\title{
Benefits of the ISO 9001 and ISO 14001 standards:
}

\section{A literature review}

\author{
Juan José Tarí1 ${ }^{1}$ José Francisco Molina-Azorín², Iñaki Heras ${ }^{3}$ \\ ${ }^{1}$ University of Alicante, ${ }^{2}$ University of Alicante, ${ }^{3}$ The University of the Basque Country UPV/EHU (Spain) \\ jj.tari@,ua.es,jf.molina@ua.es,inaki.heras@,ebu.es
}

Received: May 2012

Accepted: September 2012

\section{Abstract:}

Purpose: The purpose of this paper is to determine the similarities and differences between the benefits derived from implementing the ISO 9001 and the ISO 14001 standards.

Methodology/Approach: The paper reviews the literature using an electronic search in the ScienceDirect, $\mathrm{ABI} /$ Inform, Emerald databases to identify papers focusing on the adoption of the ISO 9001 and 14001 standards and the benefits derived from implementing them.

Findings: The paper identifies 82 articles about ISO 9001 and 29 about ISO 14001. Although some differences can be observed between the benefits considered by ISO 9001 and 14001, there is a great degree of coincidence in the benefits studied. The review suggests 13 benefits as the most usually analyzed (including environmental performance for the case of the ISO 14001 standard) by scholars. It is suggested that both standards have clear benefits on operational, people and customer results and that the effects on financial performance are inconclusive.

Limitations/implications: One limitation of this paper is that the works identified are conditioned by the search strategy used. In addition, other key words could be included in future studies such as operational, market, quality, financial performance, and customer satisfaction in order to expand this search.

Originality/Value: The main contribution is that the paper identifies the literature gap and future research proposals with regard to the benefits of the ISO 9001 and ISO 14001 standards. 
Keywords: ISO 9001, ISO 14001, benefits, performance, literature review

\section{Introduction}

Quality management (QM) and environmental management (EM) are business practices that may benefit companies. As several empirical studies show, implementing QM effectively influences firm performance positively (Powell, 1995; Samson \& Terziovski, 1999; Huarng \& Chen, 2002; Kaynak 2003; Parast, Adams \& Jones, 2011; Shahin \& Dabestani, 2011). Firms that implement QM focus on providing more value for their customers and improving the efficiency of processes. Continuous improvement of processes and product quality leads to increased revenues (through product reliability) and reduced costs (through process efficiency). In turn, customer satisfaction leads to increased revenues because it enables the firm to gain a market advantage (Kaynak, 2003; York \& Miree, 2004). Similarly, EM affects firm performance positively (Klassen \& McLaughlin, 1996; King \& Lenox, 2002; Al-Tuwaijri, Christensen \& Hughes, 2004; Moneva \& Ortas, 2010). This positive effect results from the positive impact on firm costs and differentiation levels. Pollution prevention allows savings in input and energy consumption, and increases demand among environmentally sensitive consumers (Miles \& Covin, 2000).

In this context, management system standards (MSSs) have enjoyed enormous success over the last years, both in the sphere of QM (ISO 9001) and in that of EM (ISO 14001). The first MSS appeared within the context of QM, and more specifically, in the sphere of quality assurance, which according to the definition in the ISO 8402 standard, is the set of all those planned and systematic actions applied within the framework of a Quality System, to provide adequate confidence that a product or service will satisfy given requirements for quality (ISO, 1994). By the end of 2010 at least 1.109 .905 ISO 9001 certificates had been granted in a total of 178 countries worldwide, which nearly tripled the number of certificates at the end of 2000 (ISO, 2011). After the success of the ISO 9000 standards, there followed the ISO 14000 family of standards on environmental issues. Over the last years, ISO 14001 certification has experienced a great international growth (Marimón, Casadesús \& Heras, 2010). Suffice it to say that, if by the end of 199914.106 certificates had been issued worldwide, by the end of 2010 the number of ISO 14001 certificates was 250.972 (ISO, 2011).

As various authors point out (e.g., Delmas, 2001; Braun, 2005), the ISO 9001 and 14001 standards do not refer to the compliance with a given goal or result. In other words, they are not performance standards measuring the quality of a firm's products or services or a firm's environmental results; rather, they are standards setting out the need to systematize and formalize a large number of corporate processes within a set of procedures, and to document such implementation. It must also be remembered that the implementation of this type of 
standard is a voluntary one, although in some sectors it has de facto become an obligatory measure, given the coercive influence of customers (Braun, 2005; Mendel, 2006).

Given this "non-performance" orientation of standards, a large number of studies have analyzed the benefits that may be obtained through ISO 9001 and ISO 14001 certification and implementation. In addition, some scholars have carried out literature reviews on these standards separately (Psomas \& Fotopoulos, 2009; Sampaio, Saraiva \& Rodrigues, 2009). Therefore it is interesting to analyze both standards jointly, due to the fact that both standards have many similarities in terms of their structure and dissemination processes (Corbett \& Kirsch, 2001; Corbett, 2006; Marimón, Casadesús \& Heras, 2006; Molina-Azorín, Tarí, ClaverCortés \& López-Gamero, 2009). However, to the best of our knowledge there are no literature reviews about empirical studies analyzing the benefits arising from these two standards in one single study. The purpose of this paper is to determine the similarities and differences between the benefits derived from implementing the ISO 9001 and the ISO 14001 standards (implemented separately). Based on this literature review the paper suggests future research proposals related to the measurement of certification, its interiorization and selection effect.

The paper is structured as follows. Firstly, in the methodology section, the search strategy is described. Then, the studies that have analyzed the benefits of the ISO 9001 and ISO 14001 standards are mentioned. In the discussion and conclusions section, the benefits of the two standards are compared, and some important issues are examined, such as the ISO measurement (interiorization) and selection effect in order to suggest future research proposals.

\section{Methodology}

The paper performs a literature review in order to identify empirical studies related to ISO 9001 and its benefits, and ISO 14001 and its benefits. Thus, a computer search of the ScienceDirect, ABI/Inform and Emerald databases was conducted. In the field of ISO 9001, a search was made for works that related the expressions "ISO 9000", or "ISO 9001" and "performance" or "benefits" or "profitability" in the title or the abstract of the paper. In the field of EM, the computer search was made for works that related the expressions "ISO 14000 ", or "ISO 14001" and "performance" or "benefits" or "profitability" in the title or the abstract of the paper. The list of references given in the papers found in the electronic search was also reviewed. Theoretical papers and those based on anecdotal evidence or case studies were eliminated.

The computer search found 82 empirical papers regarding the benefits of ISO 9001 . These 82 articles are reviewed in order to identify the most common benefits of the implementation of the ISO 9001 standard based on the literature, as shown in the following section. 
Following the same criterion, 29 papers were identified regarding the benefits of ISO 14001 and, as in the case of the ISO 9001 standard benefits, the most common ones are identified. Then, the paper examines the similarities and differences between the two groups of benefits and makes proposals for future research.

\section{Benefits of the ISO 9001 standard}

Many scholars have analyzed the benefits of the ISO 9001 standard in several performance dimensions (e.g. operational benefits, customer results, etc.). In this context, Table 1 shows which of these benefits are dealt with by each of the 82 studies examined, classified into the following 13 benefits:

- Market share (MS)

- Exports (EX)

- Sales and sales growth (SG)

- Profitability $(P)$

- Improvement in competitive position/competitive advantage (CA)

- Improvement in systematization (improved documentation, work procedures, clarity of work, improvement in responsibilities) (S)

- Efficiency (productivity, savings in costs, reduction in mistakes and rework, shorter lead time, improved management control) (EF)

- Improved quality in product/service (PQ)

- Improved image (I)

- Improvements in employee results (motivation, satisfaction, teams, communication, knowledge) (EMP)

- Improved customer satisfaction (reduction in complaints, etc.) (CUS)

- Improved relationships with suppliers (SUP)

- Improved relationships with authorities and other stakeholders (STA)

The present work identifies these 13 benefits because they are those most commonly analyzed by the 82 articles reviewed (see Table 1 ). 


\begin{tabular}{|c|c|c|c|c|c|c|c|c|c|c|c|c|c|}
\hline Study & MS & EX & SG & $\mathrm{P}$ & CA & $\mathrm{s}$ & $\mathrm{EF}$ & $P Q$ & I & EMP & CUS & SUP & STA \\
\hline Abraham et al. (2000) & & & & & $\mathrm{x}$ & & $x$ & $x$ & & & $\mathrm{x}$ & & \\
\hline Arauz and Suzuki (2004) & & $\mathrm{X}$ & $\mathrm{X}$ & $\mathrm{x}$ & & & $\mathrm{x}$ & & & $\mathrm{x}$ & $\mathrm{X}$ & $\mathrm{x}$ & \\
\hline Askey and Malcolm (1997) & $\mathrm{X}$ & & & & $\mathrm{X}$ & & $\mathrm{x}$ & & & & & & \\
\hline Bayati and Taghavi (2007) & & & & & & $\mathrm{X}$ & $\mathrm{X}$ & & & $\mathrm{x}$ & $\mathrm{X}$ & & \\
\hline Beirao and Cabral (2002) & & & & $\mathrm{X}$ & & & & & & & & & \\
\hline Benner and Veloso (2008) & & & & $\mathrm{X}$ & & & & & & & & & \\
\hline Beskese and Cebeci (2001) & & & & & & $\mathrm{X}$ & $\mathrm{X}$ & & $\mathrm{X}$ & & $\mathrm{X}$ & & \\
\hline Bhuiyan and Alam (2005) & & & & & & $x$ & & & & & $x$ & & \\
\hline Briscoe et al. (2005) & $\mathrm{X}$ & $\mathrm{X}$ & $\mathrm{x}$ & & & & $\mathrm{X}$ & & & & & & \\
\hline Brown et al. (1998) & $\mathrm{x}$ & $\mathrm{x}$ & & & & & $\mathrm{x}$ & $\mathrm{X}$ & $\mathrm{X}$ & $\mathrm{X}$ & & & \\
\hline Buttle (1997) & $\mathrm{X}$ & & $\mathrm{X}$ & $\mathrm{X}$ & & & $\mathrm{X}$ & & $\mathrm{X}$ & $x$ & $x$ & & \\
\hline Calisir (2007) & $\mathrm{X}$ & $\mathrm{X}$ & & $\mathrm{x}$ & & $\mathrm{X}$ & $\mathrm{x}$ & $\mathrm{X}$ & $x$ & $x$ & & & \\
\hline Casadesús and Giménez (2000) & $x$ & & $\mathrm{X}$ & $x$ & & & $\mathrm{x}$ & & & $x$ & $\mathrm{X}$ & & \\
\hline Casadesús and Karapetrovic (2005) & $\mathrm{x}$ & & $\mathrm{x}$ & $\mathrm{x}$ & & & $\mathrm{x}$ & & & $x$ & $x$ & $\mathrm{X}$ & \\
\hline Casdesús et al. (2001) & $\mathrm{x}$ & & $\mathrm{x}$ & $\mathrm{x}$ & & & $\mathrm{x}$ & & & $\mathrm{x}$ & $\mathrm{x}$ & & \\
\hline Chow-Chua et al. (2003) & & $\mathrm{x}$ & $\mathrm{X}$ & & $\mathrm{X}$ & $\mathrm{x}$ & $\mathrm{x}$ & $\mathrm{x}$ & $\mathrm{X}$ & $\mathrm{X}$ & $\mathrm{X}$ & & \\
\hline Corbett et al. (2005) & & & $\mathrm{x}$ & $\mathrm{X}$ & & & & & & & & & \\
\hline Dick et al. (2008) & 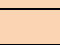 & & $\mathrm{x}$ & $\mathrm{x}$ & & & & & & & & & \\
\hline Dimara et al. (2004) & & & & $\mathrm{X}$ & & & & & & & & & \\
\hline Dissanayaka et al. (2001) & $\mathrm{X}$ & & & & $\mathrm{X}$ & $\mathrm{X}$ & $\mathrm{X}$ & & $\mathrm{X}$ & $\mathrm{X}$ & $\mathrm{X}$ & $\mathrm{X}$ & \\
\hline Dunu and Ayokanmbi (2008) & & & & $\mathrm{x}$ & & & & & & & & & \\
\hline Escanciano et al. (2001) & $\mathrm{X}$ & $x$ & $\mathrm{x}$ & & & $\mathrm{x}$ & $\mathrm{x}$ & $x$ & & $\mathrm{x}$ & $\mathrm{x}$ & $\mathrm{x}$ & \\
\hline Feng et al. (2008) & $\mathrm{x}$ & $\mathrm{x}$ & & & $\mathrm{X}$ & $\mathrm{x}$ & $\mathrm{x}$ & & $\mathrm{X}$ & $\mathrm{x}$ & & & \\
\hline Gotzamani and Tsiotras (2002) & $x$ & & $\mathrm{X}$ & & $\mathrm{x}$ & $\mathrm{x}$ & $\mathrm{x}$ & $\mathrm{x}$ & & $\mathrm{x}$ & $\mathrm{X}$ & $\mathrm{x}$ & \\
\hline Han et al. (2007) & $\mathrm{x}$ & & & & & & $\mathrm{x}$ & & & & $\mathrm{x}$ & & \\
\hline Heras et al. (2002) & & & $\mathrm{X}$ & $\mathrm{X}$ & & & & & & & & & \\
\hline Huarng (1998) & & $\mathrm{X}$ & $\mathrm{x}$ & $\mathrm{x}$ & $\mathrm{X}$ & & $\mathrm{X}$ & $\mathrm{X}$ & & & $\mathrm{X}$ & & \\
\hline Huarng et al. (1999) & & & & & & & & & & & & & \\
\hline Jang and Lin (2008) & $\mathrm{x}$ & & & $\mathrm{X}$ & & $\mathrm{x}$ & $\mathrm{X}$ & & & $\mathrm{x}$ & $\mathrm{X}$ & & \\
\hline Johnson (2004) & & & $\mathrm{X}$ & & & & $\mathrm{X}$ & & & & & & \\
\hline Jones et al. (1997) & & & $\mathrm{x}$ & & & $\mathrm{X}$ & $\mathrm{x}$ & & & & $\mathrm{X}$ & & \\
\hline Krasachol et al. (1998), & & & & & & $\mathrm{x}$ & $\mathrm{x}$ & & $\mathrm{X}$ & $\mathrm{X}$ & $\mathrm{x}$ & & \\
\hline Lee (1998) & & & $\mathrm{X}$ & & & & $x$ & & $\bar{x}$ & $\frac{x}{x}$ & $x$ & $\mathrm{x}$ & \\
\hline Lee et al. (1999) & & & & & & $\mathrm{x}$ & $\mathrm{X}$ & $x$ & $x$ & $\mathrm{X}$ & $\mathrm{X}$ & $\mathrm{X}$ & \\
\hline Leung et al. (1999) & & & $\mathrm{X}$ & & $\mathrm{X}$ & & $\mathrm{X}$ & & $\mathrm{x}$ & $\mathrm{x}$ & $\mathrm{x}$ & & \\
\hline Lima et al. (2000) & & & $x$ & $\mathrm{X}$ & & & & & & & & & \\
\hline Lo (2002) & & & & & & $\mathrm{X}$ & & & & & & & \\
\hline Lo and Chang (2007) & $\mathrm{X}$ & & & $\mathrm{X}$ & $\mathrm{X}$ & $\mathrm{x}$ & $\mathrm{X}$ & $\mathrm{x}$ & $\mathrm{X}$ & $\mathrm{X}$ & $\mathrm{X}$ & $\mathrm{X}$ & \\
\hline Magd (2006) & $\mathrm{x}$ & $x$ & & & & $x$ & $\mathrm{x}$ & $x$ & & $\mathrm{x}$ & $x$ & & \\
\hline Magd (2008) & & $\mathrm{x}$ & & $\mathrm{x}$ & & $\mathrm{x}$ & $\mathrm{x}$ & $\mathrm{x}$ & $\mathrm{x}$ & $\mathrm{x}$ & $\mathrm{x}$ & $\mathrm{x}$ & \\
\hline Magd and Curry (2003) & & $\mathrm{x}$ & & & & $\mathrm{x}$ & $\mathrm{x}$ & $\mathrm{x}$ & $\mathrm{x}$ & $\mathrm{x}$ & $\mathrm{X}$ & $\mathrm{x}$ & $\mathrm{x}$ \\
\hline Magd et al. (2003) & $\mathrm{X}$ & $\mathrm{X}$ & & $\mathrm{X}$ & & & $\mathrm{X}$ & $\mathrm{x}$ & & $\mathrm{X}$ & $\mathrm{X}$ & $\mathrm{X}$ & \\
\hline Martínez Fuentes et al. (2000) & $\mathrm{x}$ & & & & $x$ & & $\mathrm{x}$ & & $\mathrm{X}$ & & $x$ & & \\
\hline $\begin{array}{l}\text { Martínez-Costa and Martínez-Lorente } \\
\text { (2003) }\end{array}$ & & & & $\mathrm{x}$ & & & & & & & & & \\
\hline $\begin{array}{l}\text { Martínez-Costa and Martínez-Lorente } \\
\text { (2007) }\end{array}$ & & & $\mathrm{X}$ & $\mathrm{x}$ & & & & & & & & & \\
\hline Martínez-Costa et al. (2008) & $\mathrm{x}$ & & & $\mathrm{X}$ & & & $\mathrm{x}$ & & & $\mathrm{x}$ & $\mathrm{X}$ & & \\
\hline $\begin{array}{l}\text { Martínez-Lorente and Martínez-Costa } \\
(2004)\end{array}$ & & & $\mathrm{X}$ & & & & $x$ & & & & & & \\
\hline McAdam and McKeown (1999) & & & $\mathrm{X}$ & & & & $\mathrm{X}$ & & & & $\mathrm{x}$ & & \\
\hline McGuire and Dilts (2008) & & & & $\mathrm{x}$ & & & & & & & & & \\
\hline Naser et al. (2004) & & & & $\mathrm{x}$ & & & & & & & & & \\
\hline Naveh and Marcus (2004) & $\mathrm{X}$ & $\mathrm{X}$ & $\mathrm{X}$ & & & & $\mathrm{X}$ & & & & $\mathrm{X}$ & & \\
\hline Naveh and Marcus (2005) & & & & $\mathrm{X}$ & & & & & & & & & \\
\hline Nicolau and Sellers (2002) & & & & $x$ & & & & & & & & & \\
\hline Nield and Kozak (1999) & & & & & $\mathrm{X}$ & $\mathrm{x}$ & & & $\mathrm{X}$ & $\mathrm{x}$ & $\mathrm{x}$ & & \\
\hline Oliver and Qu (1999) & & & & & & & $\mathrm{x}$ & & & & $\mathrm{x}$ & & \\
\hline Pan (2003) & $\mathrm{x}$ & & & & & & $\mathrm{x}$ & & $\mathrm{X}$ & $\mathrm{X}$ & $\hat{x}$ & & $\mathrm{X}$ \\
\hline Pinar and Ozgur (2007) & & & & $\mathrm{X}$ & & & & & & & & & \\
\hline Posinska et al. (2002) & $\mathrm{x}$ & & & & & $\mathrm{X}$ & $\mathrm{X}$ & & $\mathrm{X}$ & $\mathrm{X}$ & $\mathrm{X}$ & & $\mathrm{X}$ \\
\hline Quazi and Jacobs (2004) & & & & & $\mathrm{X}$ & & & $\mathrm{x}$ & & $x$ & $\mathrm{X}$ & & \\
\hline Ragothaman and Korte (1999) & & $\mathrm{x}$ & & & & $\mathrm{X}$ & $\mathrm{X}$ & $\mathrm{x}$ & & & $\mathrm{x}$ & $\mathrm{X}$ & $\mathrm{x}$ \\
\hline Rodríguez-Escobar et al. (2006) & $\mathrm{X}$ & & & & $\mathrm{x}$ & $x$ & $\mathrm{x}$ & & $\mathrm{X}$ & $\mathrm{x}$ & $\mathrm{x}$ & $\mathrm{x}$ & \\
\hline Ruzevicius et al. (2004) & & & $\mathrm{X}$ & & & & $\mathrm{x}$ & & & & $\mathrm{x}$ & & \\
\hline Santos and Escanciano (2002) & $\mathrm{X}$ & $\mathrm{X}$ & $\mathrm{x}$ & $\mathrm{X}$ & & $\mathrm{X}$ & $x$ & $\mathrm{x}$ & $\mathrm{X}$ & $\mathrm{X}$ & $x$ & & \\
\hline Sharma (2005) & & & $\mathrm{x}$ & $\mathrm{x}$ & & & & & & & & & \\
\hline
\end{tabular}




\begin{tabular}{|c|c|c|c|c|c|c|c|c|c|c|c|c|c|}
\hline Study & MS & EX & SG & $\mathrm{P}$ & CA & $\mathrm{s}$ & $\mathrm{EF}$ & $\mathrm{PQ}$ & I & EMP & CUS & SUP & STA \\
\hline Simmons and White (1999) & $\mathrm{X}$ & $\mathrm{X}$ & & & & & & & & & & & \\
\hline Singels et al. (2001) & $\mathrm{X}$ & & $\mathrm{X}$ & & & $\mathrm{X}$ & $\mathrm{X}$ & $\mathrm{X}$ & & $\mathrm{X}$ & $\mathrm{X}$ & & \\
\hline Singh (2008) & $\mathrm{X}$ & & & $\mathrm{X}$ & & $\mathrm{X}$ & $\mathrm{X}$ & $\mathrm{X}$ & & & $\mathrm{X}$ & & \\
\hline Singh et al. (2006) & $\mathrm{X}$ & $\mathrm{X}$ & $\mathrm{X}$ & & $x$ & $\mathrm{X}$ & $\mathrm{X}$ & $\mathrm{X}$ & $\mathrm{X}$ & $x$ & $\mathrm{X}$ & $\mathrm{X}$ & \\
\hline Sun (2000) & $\mathrm{X}$ & & & & $\mathrm{X}$ & & $\mathrm{X}$ & & & $\mathrm{X}$ & $\mathrm{X}$ & & $\mathrm{X}$ \\
\hline Tan and Sia (2001) & $\mathrm{X}$ & $\mathrm{X}$ & & & & & $\mathrm{X}$ & $\mathrm{X}$ & & $\mathrm{X}$ & $\mathrm{X}$ & & \\
\hline Tang and Kam (1999) & & & & & & $\mathrm{X}$ & $\mathrm{X}$ & & $\mathrm{X}$ & & $\mathrm{X}$ & & \\
\hline Terziovski and Power (2007) & & & & $\mathrm{X}$ & & & $\mathrm{X}$ & & & & & & \\
\hline Terziovski et al. (1997) & $\mathrm{X}$ & $\mathrm{X}$ & $\mathrm{X}$ & $\mathrm{X}$ & & & $\mathrm{X}$ & & $\mathrm{X}$ & $\mathrm{X}$ & $\mathrm{X}$ & & \\
\hline Terziovski et al. (2003) & & & $\mathrm{X}$ & & & $\mathrm{X}$ & $\mathrm{X}$ & $\mathrm{X}$ & $\mathrm{X}$ & & $\mathrm{X}$ & $\mathrm{X}$ & \\
\hline Tsekouras et al. (2002) & & & & $\mathrm{X}$ & & & & & & & & & \\
\hline van der Wiele et al. (2001) & & & & & & $\mathrm{X}$ & $\mathrm{X}$ & $\mathrm{X}$ & & & $\mathrm{X}$ & & \\
\hline Vloeberghs and Bellens (1996) & & & & & & $\mathrm{X}$ & $\mathrm{X}$ & & & & $\mathrm{X}$ & & \\
\hline Wayhan et al. (2002) & & & & $\mathrm{X}$ & & & & & & & & & \\
\hline Williams (2004) & & & & & $\mathrm{X}$ & $\mathrm{X}$ & $\mathrm{X}$ & & & $\mathrm{X}$ & $\mathrm{X}$ & & \\
\hline Zaramdini (2007) & $\mathrm{X}$ & & & $\mathrm{X}$ & $\mathrm{X}$ & $\mathrm{X}$ & $\mathrm{X}$ & $\mathrm{X}$ & $\mathrm{X}$ & $\mathrm{X}$ & $\mathrm{X}$ & $\mathrm{X}$ & \\
\hline Zeng, Tian, Tam (2005) & $\mathrm{X}$ & & $\mathrm{X}$ & & & $\mathrm{X}$ & $\mathrm{X}$ & & $\mathrm{X}$ & $\mathrm{X}$ & $\mathrm{X}$ & & \\
\hline Zhao et al. (1995) & & $\mathrm{X}$ & & & $\mathrm{X}$ & $\mathrm{X}$ & $\mathrm{X}$ & & & & & & \\
\hline Total & 33 & 20 & 30 & 35 & 18 & 34 & 58 & 23 & 26 & 38 & 52 & 16 & 5 \\
\hline
\end{tabular}

Table 1. Benefits of the ISO 9001 standard

Table 1 shows that the three benefits most frequently analyzed by researchers are improved efficiency, improved customer satisfaction and improvements in relations with employees. These are followed by profitability and improved systematization. Other benefits attained by many firms, as analyzed by the studies, are an improvement in market share and sales, image, product/service quality and exports. Conversely, the three benefits least studied are an improvement in competitive position, improved relations with suppliers and improved relations with authorities and other stakeholders.

In order to analyze these benefits arising from the ISO 9001 standard, some authors examine its effects through a list of benefits, whereas others base themselves on, or even propose, a classification of such benefits. Such is the case of Lee (1998), who classifies benefits into benefits gained with respect to internal operations (better team spirit, less staff conflict, reduced wastage, increased efficiency, shorter lead time), benefits gained with respect to customer relations (improved sales through new customers, longer contracts with existing customers, less control from existing customers, fewer complaints from existing customers), and benefits gained with respect to subcontractor relations (subcontractors to become certified, better relations with subcontractors, more stringent control over subcontractors).

Nield and Kozak (1999) show that the benefits of the standard may be the following: operational benefits (improved operating systems, enhanced operating practices), marketing benefits (improved customer satisfaction, gained competitive edge, nation-wide recognition), human resources benefits (gained more committed work force, reduction in staff turnover).

Casadesús and Giménez (2000) show that these benefits are people results (work satisfaction, suggestions system, health/safety, turnover, absenteeism), operation results (errors and defects; order processing; reliability; costs; on-time-delivery; cost savings; lead time; stock rotation), customer results (customer satisfaction; complaints; repeat purchases) and financial results (market share; sales; return on sales; return on assets). 
Casadesús, Jiménez and Heras (2001) classified benefits as internal benefits and external benefits. Internal benefits are the following: work satisfaction, safety at work, suggestions system, absence from work, salaries of workers, safety and reliability, on-time delivery, order processing, number of errors, stock rotation, quality costs, cost savings. As external benefits they find the following: customer satisfaction, number of complaints, number of repeat purchases, market share, sales per employee, return on assets, return on sales.

Casadesús and Karapetrovic (2005) find that these benefits may be related to financial results (increased sales, returns on investment, market share, and sales per employee), operational results (reduced logistic costs, improved supplier relationship, increased inventory turnover, fewer non-conformities, compliance with delivery dates, and shorter lead time) and customerrelated results (loyalty purchases, customer satisfaction, and fewer complaints).

Similarly, other scholars use two general groups of benefits related to operational performance and financial performance (Naveh \& Marcus, 2004; Briscoe, Fawcett \& Todd, 2005). For example, for operational performance Naveh and Marcus (2004) show defect rate, cost of quality, productivity, on-time delivery and customer satisfaction, while Briscoe et al. (2005) list defect rate as a percent of production, cost of quality, productivity, and on-time delivery. For financial performance both studies show market share, sales, and export growth.

Based on this review, in general terms, the ISO 9001 standard creates benefits related to customer satisfaction (for instance, fewer complaints and improved customer satisfaction) (e.g., Casadesús \& Karapetrovic, 2005; Singh, 2008), improvement in staff management issues (for instance, more training for employees) (e.g., Gupta, 2000; Renuka \& Venkateshwara, 2006) and improved efficiency, documentation and clear knowledge of tasks by employees (e.g., Chow-Chua, Goh \& Wan, 2003; Magd, 2008). These results indicate that most firms experience improvement in these issues, due to the fact that the ISO 9001 standard allows them to reduce mistakes and rework, save on costs and improve the management of the firm. Many firms also attain these benefits because ISO 9001 allows for an improvement of the documentation and work procedures, and a greater clarity of work. Other benefits obtained by many firms are an improved image and an improved service or product quality, because the fact that they possess a certificate enhances their image in the eyes of their customers. In turn, the greater control exercised upon their internal processes allows them to improve the quality of the product or service.

Similarly, several studies provide evidence of certified firms outperforming non-certified firms (Heras, Dick \& Casadesús, 2002; Corbett, Montes-Sancho \& Kirsck, 2005; Sharma, 2005). This improvement is attributed largely to improvement in internal business processes. In this context, other studies also show that ISO 9001 certification is not associated with significant financial performance in the longer term, or that there is no significant difference between the impacts of quality management on financial performance for firms with and without ISO 9001 
certification (Häversjö, 2000; Singels, Ruël \& van de Water, 2001, Tsekouras, Dimara \& Skuras, 2002).

These ideas indicate that, although there are firms that do succeed in improving their financial results (for instance, their market share and their sales, because the quality certificate opens the door to certain customers), there are many others that do not manage to attain any improvement. Therefore, as the studies show, there is not such an unquestionable relationship between the standard and the financial results.

Consequently, the impact of ISO 9001 on firm performance was more mixed compared with the impact of QM on firm performance, which was much more unanimous (Martínez-Costa Martínez-Lorente \& Choi, 2008). Therefore, the clearest benefits are those influencing the internal performance or operational results, customer results and people results, while the effects on financial results are inconclusive.

\section{Benefits of the ISO 14001 standard}

As in the ISO 9001 standard field, the benefits associated with the implementation and certification of the ISO 14001 standard have also been extensively analyzed in the academic literature. The main benefits identified in the empirical literature are presented in Table 2 following the classification shown in Table 1, but in addition to these an extra specific benefit has been identified, environmental performance (ENVP), because scholars have used it extensively.

Table 2 shows that the three benefits most considered by the studies identified are environmental performance, efficiency and profitability. Other benefits which have also merited great attention are improved image, improvement in customer satisfaction, improved staff results, improved competitive edge and improved relations with stakeholders. Conversely, the benefits least considered in the empirical studies analyzed are improved sales, improved product quality and increased market share.

As was the case with the studies on ISO 9001, some studies analyzing the ISO 14001 standard have also proposed several groups of benefits. For instance, Poksinska Dahlgaard and Eklund (2003) pointed out three groups of benefits: internal performance benefits (cost reductions, environmental improvements, increased productivity, increased profit margin, improved internal procedures, improved employee morale), external marketing benefits (improved corporate image, increased market share, increased customer satisfaction, increased on-time delivery to customers) and relations benefits (improved relations with communities, improved relations with authorities). 


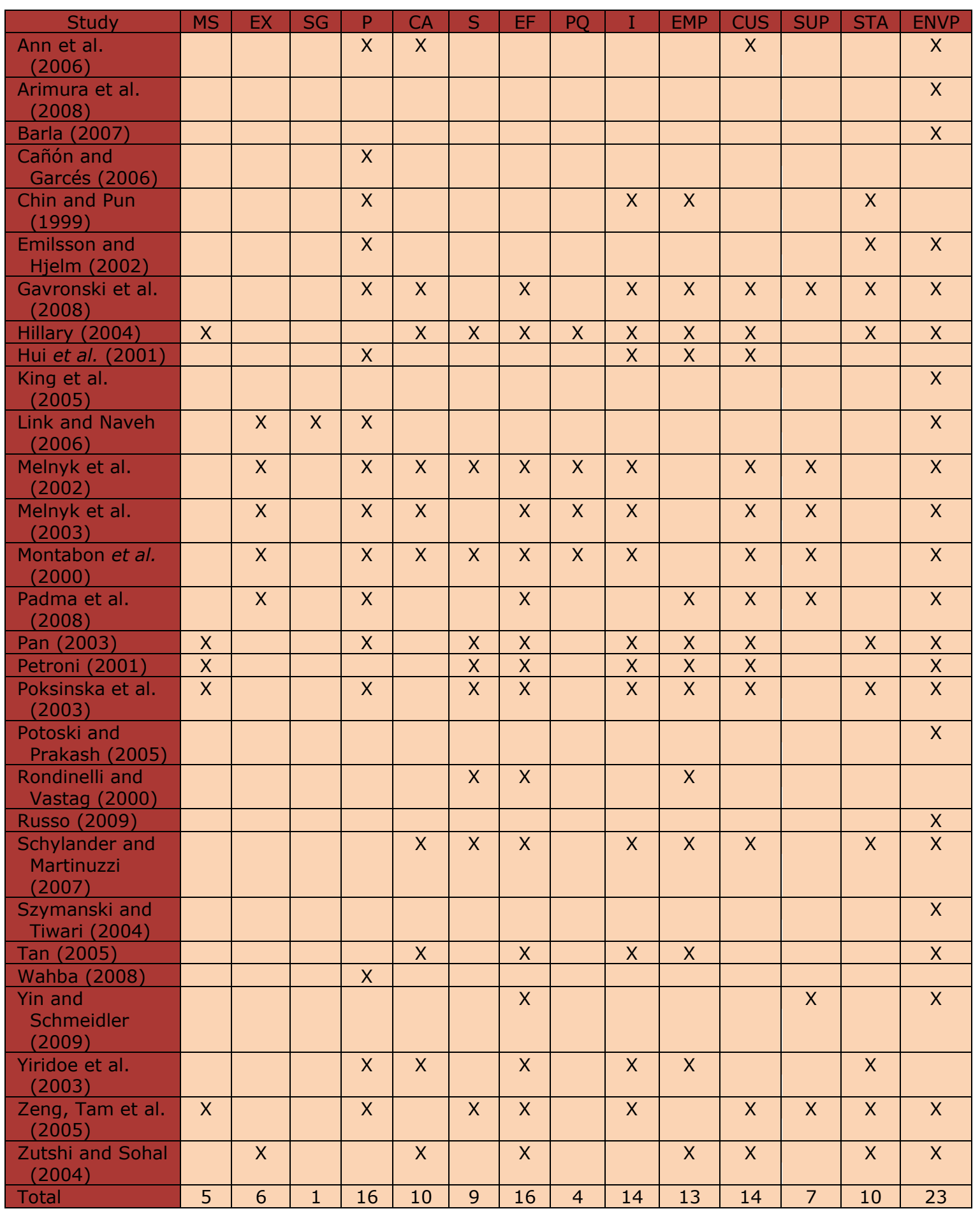

Table 2. Benefits of the ISO 14001 standard

Hillary (2004) distinguished between internal and external benefits. In addition, this author divided internal benefits in several groups: organizational benefits (quality of management, quality of training, working conditions and safety, quality of environmental information, legal compliance, encouragement of innovation, improved procedures, strategic overview of environmental responsibility), financial benefits (cost savings from material, energy and waste reductions), and people benefits (increased employee motivation, enhanced skills, better company image among employees, forum for dialogue between staff and management). 
External benefits may also be divided into different groups: commercial benefits (gaining new customers/business and satisfying existing customers, gaining competitive/marketing advantage, staying in business, developing more environmentally friendly products), environmental benefits (improved environmental performance, assured legal compliance, increased energy and material efficiencies, reduced pollution), and communication benefits (positive public image, better customer relationships, better cooperation and relationships with regulators and administrative bodies, improved communication with stakeholders, setting an example for other companies in a sector).

Zeng, Tian and Shi (2005) also considered several groups of benefits: internal operations (enhanced efficiency, well-defined responsibility, enhanced environmental awareness, standardization of environmental management), corporate management (fewer complaints, improved profitability, savings in resources and reduced wastage, increased social recognition), marketing effects (enlarged market share, confidence from customers, improved corporate image), and supplier relations (better relations with suppliers, more stringent control over suppliers, promoting ISO 14001 certification to suppliers, enhanced environmental awareness of suppliers).

Link and Naveh (2006) distinguished between environmental performance (pollution emission, use of recycled materials and other environmental aspects) and business performance (annual gross profit margin, investment in R\&D, sales, sales per employee and business with foreign organizations).

Gavronski, Ferrer and Paiva (2008) emphasized four groups of benefits: productivity benefits (resource usage reduction, optimization of process flows, production costs reduction, better employee motivation), financial benefits (opportunity to obtain investment funds from governmental organizations, access to special credit with reduced interest rates, reduction of insurance premiums), market benefits (competitive advantages, positive effects on the market and with customers, opportunity to set an example for suppliers) and societal benefits (improved corporate image for society in general, reduced environmental liability, improved cooperation from environmental authorities).

As in the case of the ISO 9001 standard, in general terms the studies show that the ISO 14001 standard has a significant impact on a high number of benefits. However, some studies have found no positive relation between the implementation of ISO 14001 and performance. For example, Cañón and Garcés (2006), through an event study, found that ISO 14001 certification had a negative impact on stock price. Besides, Link and Naveh (2006) found that, although greater management standardization in environmental issues does lead to better environmental performance, such environmental performance does not have an influence upon business performance. 
Consequently, the implementation of the ISO 14001 standard has clear benefits on operational results (e.g. people and other stakeholder results, saving in costs) and the effects on financial results are inconclusive.

\section{Discussion and conclusions}

This paper carries out a literature review on the ISO 9001 and ISO 14001 standards and their benefits, in order to examine the benefits analyzed and the similarities and differences regarding these benefits in these two standards. On the basis of this analysis the paper suggests several ideas about similarities and differences, classification of benefits, interiorization, integration, and the selection effect.

First, Tables 1 and 2 show that the benefits most analyzed by researchers, both concerning ISO 9001 and ISO 14001, are improved efficiency and profitability, improved customer satisfaction, improved relationship with staff and image. Other benefits analyzed for ISO 9001, although to a lesser extent, are market share, sales and product quality. These three benefits are those least analyzed for the ISO 14001 standard. Moreover, the environmental performance, the most common benefit in the ISO 14001 standard, has not been examined by the ISO 9001 standard. In addition, relationship with stakeholders is considered by a high number of studies in ISO 14001 but is the least studied by the ISO 9001 literature.

Second, in general terms, the benefits of ISO 9001 and ISO 14001 may be classified into internal and external ones. Other studies propose a wider classification, including peoplerelated, operational, customer and financial benefits, which in turn could be then divided into internal and external. According to these studies, internal benefits include improvements in corporate processes having positive effects on operational and people issues (e.g. increase in productivity, improvement in efficiency and reduction in costs and waste, training). External benefits relate to effects on customers and society in general (e.g. customer satisfaction, better relationships with stakeholders, improved image). In this context, some studies classify financial results as external benefits and others as internal benefits.

Consequently, in this context, both standards show clear benefits on certain issues, such as efficiency, employees, systematization, customers and other stakeholders, which indicates that, in general terms, certified firms improve people, operational and stakeholder performance. Nevertheless, only some certified firms do better than non-certified firms regarding financial performance. As is pointed out in the previous section, both for ISO 9001 and for ISO 14001, studies can be found showing that there is no impact on financial performance. Therefore, although the standards do create internal and external benefits, and therefore many of them have a positive effect upon people, operational issues and stakeholders, the relationship between these standards and financial performance is not so clear. 
Third, several scholars show that more internally motivated firms saw better performance outcomes, for both internal and external performance, both for ISO 9001 (Lee, 1998, Jones, Arndt \& Kustin, 1997; Singels et al., 2001; Boiral \& Roy, 2007; Martínez-Costa et al., 2008) and for ISO 14001 (Boiral \& Sala, 1998; Rondinelli \& Vastag, 2000; Kitazawa \& Sarkis, 2000). This idea suggests the view of a few articles trying to explain better the relationship between both standards and performance. In this context, these few articles show that certification in itself leads to few benefits. However, when a firm really applies the quality system underlying the standard, and there is a real commitment to quality and to the environment, that is, when the standards are interiorized, there is an increased possibility of attaining the benefits listed, including the financial ones. Therefore, a way of explaining better the effects of both standards on performance is including variables related to motives for certification in future research studies.

In this context, an important issue in the works identified is the measurement of certification. Most of the studies analyzing the benefits of ISO 9001 and 14001 consider a dichotomic variable to see whether the firm is certified or not, but do not analyze the degree of commitment, implementation, or internalization of, the ISO standards. In this respect, many studies measuring QM have used a number of practices in order to measure it as a multidimensional construct (Powell, 1995; Kaynak, 2003; Prajogo \& Sohal, 2006). For instance, those works measuring QM as a multidimensional construct use practices like the following: leadership, people management, customer management, relationships with suppliers, process management and information and analysis. Each of these constructs is measured through a set of items. In this way, the authors may analyze the QM level, and thus examine if a higher level in QM leads to increased results. In the field of EM there are also studies measuring the degree of environmental proactiveness using various practices and critical factors for implementation (Quazi, 1999; Kitazawa \& Sarkis, 2000; Lin, Jones \& Hsieh, 2001; Govindarajulu \& Daily, 2004; González-Benito \& González-Benito, 2005; Wee \& Quazi, 2005).

These issues have been little analyzed in the case of ISO 9001 and ISO 14001. Thus, for instance, only a few authors have measured the ISO 9001 variable as a set of dimensions made up of various items, in order to examine the degree of interiorization of the variable. This indicates that few studies have used ISO 9000 key management practices to assess ISO 9000 and then analyzed their effects on firm performance, as many studies about QM have done measuring QM as a multidimensional construct. For example, Naveh and Marcus (2004) used several measures to examine the adoption of the ISO 9001 standard (e.g. going beyond; used in daily practice; applied to solving problems; integrated; kept current; externally coordinated). Their results show that the impact of ISO 9001 on performance depends on the level of assimilation (i.e. the degree to which the practice makes its way into various aspects of the organizational life) and the degree to which the organization goes beyond the minimal 
practice requirements. More success is achieved if there is both thorough assimilation of the practice and the firm goes beyond what the practice requires. Then, though the ISO 9001 standard itself is homogenous, the way a firm implements it introduces variations that can distinguish the organization from its competitors in operating performance and in this way gives the individual organization an advantage (Naveh \& Marcus, 2004; 2005). Similarly, Singh (2008) identified a validated framework for effective implementation of ISO 9000 . The author used six constructs to measure management practices associated with the standard: management policies, plans and actions; focus on customers; capable employees; reliable suppliers; sound communication system; and steady processes. These ideas suggest that quality certification may be important for competitiveness, but it is the way such certification is implemented and internalized that makes it possible to derive the benefits described by the literature. Thus, when certification is used in daily practice and as a catalyst for change, the organization could achieve a distinct operating advantage from implementation (Naveh \& Marcus, 2005).

Studies on ISO 14001 that emphasize this idea can also be found. Link and Naveh (2006) point out that, for this standard to be really effective, it must be made a part of daily work. These authors measured the degree of standardization, considering the degree to which ISO 14001 rules, policies, and procedures govern the managing of organizational environmental issues, using six items from Naveh and Marcus (2004). Schylander and Martinuzzi (2007) pointed out that, in order to develop an ISO 14001 environmental management system into a sustainability management system, the two most important challenges are to improve coordination between the EM and the organization's strategies and to synchronize the EM with central value chains. Quazi (2001) emphasized that environmental management should be integrated into the organizational strategic planning process. Yin and Schmeidler (2009) indicated that standardized management systems may be implemented very differently in different organizations. According to these scholars, this variability in implementation may be responsible for the heterogeneous performance of these standardized systems, and they emphasize that the current literature on the environmental impacts of ISO 14001 certification has largely neglected this phenomenon. These authors considered the integration of ISO 14001 standards into daily operations, and the inclusion of performance management elements in the ISO 14001 standard.

Therefore, another way of explaining better the relationship between the two standards and performance in future research is considering the elements of internalization of both standards, apart from the certification and non-certification variable.

Fourth, many similarities exist between QM and EM systems. For example, their purposes and implementation-related factors are very much alike. Considering these parallels, and since research on QM is more fully developed than that on EM, significant benefits can be expected 
from applying the knowledge acquired about QM to environmental issues (Klassen \& McLaughlin, 1993; Curkovic, 2003). Moreover, an integrated system adds a number of benefits to those achieved by each of the systems alone. Among these benefits, the literature highlights the following (Wilkinson \& Dale, 1999a, 1999b; Poksinska et al. 2003; Zeng, Tian \& Shi, 2005; Zutshi \& Sohal, 2005):

- An improvement in the efficiency and effectiveness of the organization, avoiding the duplication of efforts,

- A reduction of bureaucracy by eliminating duplication of policies, procedures and registers,

- The alignment of goals, processes and resources,

- A reduction in the costs of internal and external audits, and

- The availability of joint training and improved communication between all organizational levels.

Finally, it was considered that an important issue regarding benefits is the analysis of whether there is a treatment effect and a selection effect. For instance, in the case of financial benefits, it would be interesting to know if the implementation of the standards leads to an improvement in these financial benefits (treatment effect) or if, on the contrary, it is precisely those firms with relative financial benefits over the average in the sector that are most likely to obtain certification (selection effect). In this respect, there a number of studies in the field of the ISO 9001 standard (Heras et al., 2002; Dick, Heras \& Casadesús, 2008) which show the existence of both effects. In our opinion, new studies should be carried out regarding this issue for the various indicators of firm performance reviewed.

This work supplements previous literature reviews (Psomas \& Fotopoulos, 2009; Sampaio et al., 2009), expanding them because it includes in a single study both standards and suggest ideas not analyzed in these previous literature reviews related to other issues, such as internalization and selection effect.

In addition, the work can be used in teaching to explain better the whole benefits of both standards and in which circumstances there is a greater probability that these benefits should happen. Also, it contributes to the academic literature showing the most common benefits between the two standards to examine in future research, as well as some differences between the two standards.

Finally, based on these ideas, research proposals for future research in terms of the benefits gains from implementing ISO 9001 and ISO 14001 can be suggested. First, future studies could analyze the effects of both standards on performance measuring the 13 benefits identified here, or at least some of them. Second, future studies should consider other 
variables to explain better these relationships, such as motives for certification and/or the level of internalization of both standards. Third, future studies also could supplement this kind of studies by examining the selection effects. Fourth, studies about integration could be interesting due to the similarities between the two standards.

\section{References}

Abraham, M., Crawford, J., Carter, D., \& Mazotta, F. (2000). Management decisions for effective ISO 9000 accreditation. Management Decision, 38(3), 182-93. http://dx.doi.org/10.1108/EUM000000005346

Al-Tuwaijri, S., Christensen, T., \& Hughes, K. (2004). The relations among environmental disclosure, environmental performance, and economic performance: a simultaneous equations approach. Accounting, Organizations and Society, 29, 447-71. http://dx.doi.org/10.1016/S0361-3682(03)00032-1

Ann, G., Zailani, S., \& Wahid, N. (2006). A study on the impact of environmental management system (EMS) certification towards firms' performance in Malaysia. Management of Environmental Quality, 17, 73-93. http://dx.doi.org/10.1108/14777830610639459

Arauz, R., \& Suzuki, H. (2004). ISO 9000 performance in Japanese industries. Total Quality Management \& Business Excellence, 3-33. http://dx.doi.org/10.1080/1478336032000149072

Arimura, T., Hibiki, A., \& Katayama, H. (2008). Is a voluntary approach an effective environmental policy instrument? A case for environmental management systems. Journal of Environmental Economics Management, 55, 281-95. http://dx.doi.org/10.1016/j.jeem.2007.09.002

Askey, J.M., \& Malcolm, A. (1997). Quality management in the UK advertising industry. International Journal of Quality \& Reliability Management, 14(2), 186-96. http://dx.doi.org/10.1108/02656719710165446

Barla, P. (2007). ISO 14001 certification and environmental performance in Quebec's pulp and paper industry. Journal of Environmental Economics and Management, 53, 291-306. http://dx.doi.org/10.1016/j.jeem.2006.10.004

Bayati, A., \& Taghavi, A. (2007). The impacts of acquiring ISO 9000 certification on the performance of SMEs in Tehran. The TQM Magazine, 19(2), 140-9. http://dx.doi.org/10.1108/09544780710729980

Beirao, G., \& Cabral, J.A.S. (2002). The reaction of the Portuguese stock market to ISO 9000 certification. Total Quality Management, 13(4), 465-74. http://dx.doi.org/10.1080/09544120220149278

Benner, M.J., \& Veloso, F.M. (2008). ISO 9000 practices and financial performance: a technology coherence perspective. Journal of Operations Management, 26, 611-29. http://dx.doi.org/10.1016/j.jom.2007.10.005 
Beskese, A., \& Cebeci, U. (2001) Total quality management and ISO 9000 applications in Turkey. The TQM Magazine, 13(1), 69-73. http://dx.doi.org/10.1108/09544780110359392

Bhuiyan, N., \& Alam, N. (2005). An investigation into issues related to the lates version of ISO 9000. Total Quality Management \& Business Excellence, 16(2), 199-213. http://dx.doi.org/10.1080/14783360500054343

Boiral, O., \& Roy, M.J. (2007). ISO 9000: integration rationales and organizational impacts. International Journal of Operations \& Production Management, 27, 226-47. http://dx.doi.org/10.1108/01443570710720630

Boiral, O., \& Sala, J.M. (1998). Environmental management: should industry adopt ISO 14001. Business Horizons, 41, 57-64. http://dx.doi.org/10.1016/S0007-6813(98)90065-9

Braun, B. (2005). Building global institutions: the diffusion of management standards in the world economy - an institutional perspective, in Alvstam, C.G. and Schamp, E.W. (Eds), Linking Industries Across the World, Ashgate, London, 3-27.

Briscoe, J.A., Fawcett, S.E., \& Todd, R.H. (2005). The implementation and impact of ISO 9000 among small manufacturing enterprises. Journal of Small Business Management, 43(3), 30930. http://dx.doi.org/10.1111/j.1540-627X.2005.00139.x

Brown, A., Van der Wiele, T., \& Loughton, K. (1998). Smaller enterprises' experiences with ISO 9000. International Journal of Quality \& Reliability Management, 15(3), 273-85. http://dx.doi.org/10.1108/02656719810198935

Buttle, F. (1997). ISO 9000: marketing motivations and benefits. International Journal of Quality \& Reliability Management, 14(9), 936-47. http://dx.doi.org/10.1108/02656719710186867

Calisir, F. (2007). Factors affecting service companies' satisfaction with ISO 9000. Managing Service Quality, 17(5), 579-93. http://dx.doi.org/10.1108/09604520710817370

Cañón, J., \& Garcés, C. (2006). Repercusión económica de la certificación medioambiental ISO 14001. Cuadernos de Gestión, 6, 45-62.

Casadesús, M., \& Giménez, G. (2000). The benefits of the implementation of the ISO 9000 standard: empirical research in 288 Spanish companies. The TQM Magazine, 12(6), 432-41. http://dx.doi.org/10.1108/09544780010351751

Casadesús, M., \& Karapetrovic, S. (2005). The erosion of ISO 9000 benefits: a temporal study. International Journal of Quality \& Reliability Management, 22(2), 120-36. http://dx.doi.org/10.1108/02656710510577198

Casadesús, M., Giménez, G., \& Heras, I. (2001). Benefits of ISO 9000 implementation in Spanish industry. European Business Review, 13(6), 327-35. http://dx.doi.org/10.1108/EUM0000000006195

Chin, K., \& Pun, K. (1999). Factor influencing ISO 14000 implementation in printed circuit board manufacturing industry in Hong Kong. Journal of Environmental Planning and Management, 42, 123-34. http://dx.doi.org/10.1080/09640569911334 
Chow-Chua, C., Goh, M., \& Wan, T.B. (2003). Does ISO 9000 certification improve business performance? International Journal of Quality \& Reliability Management, 20(8), 936-53. http://dx.doi.org/10.1108/02656710310493643

Corbett, C.J. (2006). Global diffusion of ISO 9000 certification through supply chains. Manufacturing and Service Operations Management, 8, 330-50. http://dx.doi.org/10.1287/msom.1060.0120

Corbett, C.J., \& Kirsch, D.A. (2001). International diffusion of ISO 14000 certification. Production and Operations Management, 10, 327-42. http://dx.doi.org/10.1111/j.19375956.2001.tb00378.x

Corbett, C.J., Montes-Sancho, M.J., \& Kirsck, D.A. (2005). The financial impact of ISO 9000 certification in the United States: An empirical analysis. Management Science, 51(7), 104659. http://dx.doi.org/10.1287/mnsc. 1040.0358

Curkovic, S. (2003). Environmentally Responsible Manufacturing: The development and validation of a measurement model, European Journal of Operational Research, 146, 130-55. http://dx.doi.org/10.1016/S0377-2217(02)00182-0

Delmas, M. (2001). Stakeholders and competitive advantage: the case of ISO 14001. Production and Operations Management, 10, 343-58. http://dx.doi.org/10.1111/j.19375956.2001.tb00379.x

Dick, G.P.M., Heras, I., \& Casadesús, M. (2008). Shedding light on causation between ISO 9001 and improved business performance. International Journal of Operations \& Production Management, 28(7), 687-708. http://dx.doi.org/10.1108/01443570810881811

Dimara, E., Skuras, D., Tsekouras, K., \& Goutsos, S. (2004). Strategic orientation and financial performance of firms implementing ISO 9000. International Journal of Quality \& Reliability Management, 21(1), 72-89. http://dx.doi.org/10.1108/02656710410511704

Dissanayaka, S.M., Kumaraswamy, M.M., Karim, K., \& Marosszeky, M. (2001). Evaluating outcomes from ISO 9000-certified quality systems of Hong Kong constructors. Total Quality Management, 12(1), 29-40. http://dx.doi.org/10.1080/09544120020010075

Dunu, E.S., \& Ayokanmbi, M.F. (2008). The impact of IOS 9000 certification on the financial performance of organizations. Journal of Global Business Issues, 2, 135-44.

Emilsson, S., \& Hjelm, O. (2002). Implementation of standardised environmental management systems in Swedish local authorities: reasons, expectations and some outcomes. Environmental Science \& Policy, 5, 443-8. http://dx.doi.org/10.1016/S1462-9011(02)00090-4

Escanciano, C., Fernández, E., \& Vázquez, C. (2001). ISO 9000 certification and quality management in Spain: results of a national survey. The TQM Magazine, 13(3), 192-200. http://dx.doi.org/10.1108/09544780110385500

Feng, M., Terziovski, M., \& Samson, D. (2008). Relationship of ISO 9001:2000 quality system certification with operational and business performance. A survey in Australia and New Zealand-based manufacturing and service companies. Journal of Manufacturing Technology Management, 19(1), 22-37. http://dx.doi.org/10.1108/17410380810843435 
Gavronski, I., Ferrer, G., \& Paiva, E. (2008). ISO 14001 certification in Brazil: motivations and benefits. Journal of Cleaner Production, 16, 87-94. http://dx.doi.org/10.1016/j.jclepro.2006.11.002

González-Benito, J., \& González-Benito, O. (2005). Environmental proactivity and business performance: an empirical analysis. Omega, 33, 1-15. http://dx.doi.org/10.1016/j.omega.2004.03.002 Gotzamani, K.D., \& Tsiotras, G.D. (2002). The true motives behind ISO 9000 certification. Their effect on the overall certification benefits and long term contribution towards TQM. International Journal of Quality \& Reliability Management, 19(2), 151-69. http://dx.doi.org/10.1108/02656710210413499

Govindarajulu, N., \& Daily, B. (2004). Motivating employees for environmental improvement. Industrial Management \& Data Systems, 104, 364-72. http://dx.doi.org/10.1108/02635570410530775 Gupta, A. (2000). Quality management practices of ISO vs non-ISO companies: a case of Indian industry. Industrial Management \& Data Systems, 100, 451-55. http://dx.doi.org/10.1108/02635570010358357

Han, S.B., Chen, S.K., \& Ebrahimpour, M. (2007). The impact of ISO 9000 on TQM and business performance. Journal of Business and Economic Studies, 13(2), 1-23.

Häversjö, T. (2000). The financial effects of ISO 9000 registration for Danish companies. Managerial Auditing Journal, 15, 47-52. http://dx.doi.org/10.1108/02686900010304632

Heras, I., Dick, G.P.M., \& Casadesús, M. (2002). ISO 9000 registration's impact on sales and profitability. A longitudinal analysis of performance before and after accreditation. International Journal of Quality \& Reliability Management, 19(6), 774-91. http://dx.doi.org/10.1108/02656710210429618

Hillary, R. (2004). Environmental management systems and the smaller enterprise. Journal of Cleaner Production, 12, 561-9. http://dx.doi.org/10.1016/j.jclepro.2003.08.006

Huarng, F. (1998). Integrating ISO 9000 with TQM spirits: a survey. Industrial Management \& Data System, 98(8), 373-9. http://dx.doi.org/10.1108/02635579810243889

Huarng, F., \& Chen, Y.T. (2002). Relationships of TQM philosophy, methods and performance: a survey in Taiwan. Industrial Management \& Data Systems, 102, 226-34. http://dx.doi.org/10.1108/02635570210423271

Huarng, F., Horng, C., \& Chen, C. (1999). A study of ISO 9000 process, motivation and performance. Total Quality Management, 10(7), 1009-25. http://dx.doi.org/10.1080/0954412997190 Hui, I., Chan, A., \& Pun, K. (2001). A study of the environmental management system implementation practices. Journal of Cleaner Production, 9, 269-76. http://dx.doi.org/10.1016/S0959-6526(00)00061-5

ISO (1994). ISO 8402:1994 Standard ${ }_{\llcorner}$Quality Management and Quality Assurance, Vocabulary, Geneva.

ISO (2011). The ISO Survey of ISO 9000 and ISO 14000 Certifications: 20th Cycle, Geneva. Jang, W-Y., \& Lin, C.I. (2008). An integrated framework for ISO 9000 motivation, depth of ISO 9000 implementation and firm performance. The case of Taiwan. Journal of Manufacturing Technology Management, 19(2), 194-216. http://dx.doi.org/10.1108/17410380810847918 
Johnson, D.M. (2004). Empirical study of QS 9000 using principal components analysis and robust regression. The Quality Management Journal, 11(1), 33-46.

Jones, R., Arndt, G., \& Kustin, R. (1997). ISO 9000 among Australian companies: impact of time and reasons for seeking certification on perceptions of benefits received. International Journal of Quality \& Reliability Management, 14(7), 650-60. http://dx.doi.org/10.1108/02656719710173258

Kaynak, H. (2003). The relationship between total quality management practices and their effects on firm performance. Journal of Operations Management, 21, 405-35. http://dx.doi.org/10.1016/S0272-6963(03)00004-4

King, A., \& Lenox, M. (2002). Exploring the locus of profitable pollution reduction. Management Science, 48, 289-99. http://dx.doi.org/10.1287/mnsc.48.2.289.258

King, A., Lenox, M., \& Terlaak, A. (2005). The strategic use of decentralized institutions: exploring certification with the ISO 14001 management standard. Academy of Management Journal, 48, 1091-106. http://dx.doi.org/10.5465/AMJ.2005.19573111

Kitazawa, S., \& Sarkis, J. (2000). The relationship between ISO 14001 and continuous source reduction programs. International Journal of Operations and Production Management, 20, 225-48. http://dx.doi.org/10.1108/01443570010304279

Klassen, R., \& McLaughlin, C. (1993). TQM and environmental excellence in manufacturing. Industrial Management \& Data Systems, 93, 14-22. http://dx.doi.org/10.1108/02635579310040924

Klassen, R., \& McLaughlin, C. (1996). The impact of environmental management on firm performance. Management Science, 42, 1199-214. http://dx.doi.org/10.1287/mnsc.42.8.1199

Krasachol, L., Willey, P. C. T., \& Tannock, J. D. T. (1998). The progress of quality management in Thailand. The TQM Magazine, 10(1), 40-4. http://dx.doi.org/10.1108/09544789810197837

Lee, T.Y. (1998). The development of ISO 9000 certification and the future of quality management: a survey of certification firms in Hong Kong. International Journal of Quality \& Reliability Management, 15(2), 162-77. http://dx.doi.org/10.1108/02656719810204766

Lee, T.Y., Leung, H.K.N., \& Chan, K.C.C. (1999). Improving quality management on the basis of ISO 9000. The TQM Magazine, 11(2), 88-94. http://dx.doi.org/10.1108/09544789910257028

Leung, H.K.N., Chan, K.C.C., \& Lee, T.Y. (1999). Cost and benefits of ISO 9000 series, a practical study. International Journal of Quality \& Reliability Management, 16(7), 675-90. http://dx.doi.org/10.1108/02656719910283362

Lima, M.A.M., Resende, M., \& Hasenclever, L. (2000). Quality certification and performance of Brazilian firms: an empirical study. International Journal of Production Economics, 66(2), 143-54. http://dx.doi.org/10.1016/S0925-5273(99)00118-8

Lin, B., Jones, C., \& Hsieh, C. (2001). Environmental practices and assessment: a process perspective. Industrial Management \& Data Systems, 101, 71-9. http://dx.doi.org/10.1108/02635570110384348 
Link, S., \& Naveh, E. (2006). Standardization and discretion: does the environmental standard ISO 14001 lead to performance benefits? IEEE Transactions on Engineering Management, 53, 508-19. http://dx.doi.org/10.1109/TEM.2006.883704

Lo, L.K., \& Chang, D.S. (2007). The difference in the perceived benefits between firms that maintain ISO certification and those that do not. International Journal of Production Research, 48(5), 1881-97. http://dx.doi.org/10.1080/00207540600733709

Lo, T.Y. (2002). Quality culture: a product of motivation within organization. Managerial Auditing Journal, 17(5), 272-76. http://dx.doi.org/10.1108/02686900210429704

Magd, H., \& Curry, A. (2003). An empirical analysis of management attitudes towards ISO 9001:2000 in Egypt. The TQM Magazine, 15(6), 381-90. http://dx.doi.org/10.1108/09544780310502714

Magd, H., Kadasah, N., \& Curry, A. (2003). ISO 9000 implementation: a study of manufacturing companies in Saudi Arabia. Managerial Auditing Journal, 18(4), 313-22. http://dx.doi.org/10.1108/02686900310488258

Magd, H.A.E. (2006). An investigation of ISO 9000 adoption in Saudi Arabia. Managerial Auditing Journal, 21(2), 132-47. http://dx.doi.org/10.1108/02686900610639284

Magd, H.A.E. (2008). ISO 9001:2000 in the Egyptian manufacturing sector: perceptions and perspectives. International Journal of Quality \& Reliability Management, 25(2), 173-200. http://dx.doi.org/10.1108/02656710810846934

Marimón, F., Casadesús, M., \& Heras, I. (2006). ISO 9000 and ISO 14000 standards: an international diffusion model. International Journal of Operations and Production Management, 26, 141-65. http://dx.doi.org/10.1108/01443570610641648

Marimón, F., Casadesús, M., \& Heras, I. (2010). Certification intensity level of the leading nations in ISO 9000 and ISO 14000 standards. International Journal of Quality \& Reliability Management, 27(9), 1002-1020. http://dx.doi.org/10.1108/02656711011084800

Martínez Fuentes, C., Balbastre Benavent, F., Escriba Moreno, M.A., González Cruz, T., \& Pardo del Val, M. (2000). Analysis of the implementation of ISO 9000 quality assurance systems. Work Study, 49(6), 229-41. http://dx.doi.org/10.1108/00438020010343408

Martínez-Costa, M., \& Martínez-Lorente, A.R. (2003). Effects of ISO 9000 certification on firms' performance: A vision from the market. Total Quality Management \& Business Excellence, 14(10), 1179-91. http://dx.doi.org/10.1080/1478336032000107735

Martínez-Costa, M., \& Martínez-Lorente, A.R. (2007). A triple analysis of ISO 9000 effects on company performance. International Journal of Productivity and Performance Management, 56(5/6), 484-99. http://dx.doi.org/10.1108/17410400710757150

Martínez-Costa, M., Martínez-Lorente, A.R., \& Choi, T.Y. (2008). Simultaneous consideration of TQM and ISO 9000 on performance and motivation: an empirical study of Spanish companies. International Journal of Production Economics, 113, 23-39. http://dx.doi.org/10.1016/j.ijpe.2007.02.046 
Martínez-Lorente, A.R., \& Martínez-Costa, M. (2004). ISO 9000 and TQM: substitutes or complementaries. International Journal of Quality \& Reliability Management, 21(3), 260-76. http://dx.doi.org/10.1108/02656710410522711

McAdam, R., \& McKeown, M. (1999). Life after ISO 9000, An analysis of the impact of ISO 9000 and total quality management on small businesses in Northern Ireland. Total Quality Management, 10(2), 229-41. http://dx.doi.org/10.1080/0954412997974

McGuire, S.J., \& Dilts, D.M. (2008). The financial impact of standard stringency: an event study of successive generations of the ISO 9000 standard. International Journal of Production Economics, 113, 3-22. http://dx.doi.org/10.1016/j.ijpe.2007.02.045

Melnyk, S., Sroufe, R., Calantone, R., \& Montabon, F. (2002). Assessing the effectiveness of US voluntary environmental programmes: an empirical study. International Journal of Production Research, 40, 1853-78. http://dx.doi.org/10.1080/00207540110118398

Melnyk, S., Sroufe, R., \& Calantone, R. (2003). Assessing the impact of environmental management systems on corporate and environmental performance. Journal of Operations Management, 21, 329-51. http://dx.doi.org/10.1016/S0272-6963(02)00109-2

Mendel, P.J. (2006). The Making and Expansion of International Management Standards: The global Diffusion of ISO 9000 Quality Management Certificates, Oxford University Press, New York.

Miles, M., \& Covin, J. (2000) Environmental marketing: a source of reputational, competitive, and financial advantage. Journal of Business Ethics, 23, 299-311. http://dx.doi.org/10.1023/A:1006214509281

Molina-Azorín, J.F., Tarí, J.J., Claver-Cortés, E., \& López-Gamero, M.D. (2009). Quality management, environmental management and firm performance: a review of empirical studies and issues of integration. International Journal of Management Reviews, 11(2), 197222. http://dx.doi.org/10.1111/j.1468-2370.2008.00238.x

Moneva, J., \& Ortas, E. (2010). Corporate environmental and financial performance: a multivariate approach. Industrial Management \& Data Systems, 110, 193-210. http://dx.doi.org/10.1108/02635571011020304

Montabon, F., Melnyk, S., Sroufe, R., \& Calantone, R. (2000). ISO 14000: assessing its perceived impact on corporate performance. Journal of Supply Chain Management, Spring, 416. http://dx.doi.org/10.1111/j.1745-493X.2000.tb00073.x

Naser, K., Karbhari, Y., \& Mokhtar, M.Z. (2004). Impact of ISO 9000 registration on company performance. Evidence from Malaysia. Managerial Auditing Journal, 14(4), 509-16. http://dx.doi.org/10.1108/02686900410530510

Naveh, E., \& Marcus, A. (2005). Achieving competitive advantage through implementing a replicable management standard: installing and using ISO 9000. Journal of Operations Management, 24, 1-26. http://dx.doi.org/10.1016/j.jom.2005.01.004 
Naveh, E., \& Marcus, A.A. (2004). When does the ISO 9000 quality assurance standard lead to performance improvement? Assimilation and going beyond. IEEE Transactions of Engineering Management, 51, 352-63. http://dx.doi.org/10.1109/TEM.2004.830864

Nicolau, J.L., \& Sellers, R. (2002). The stock market's reaction to quality certification: Empirical evidence from Spain. European Journal of Operational Research, 142, 632-41. http://dx.doi.org/10.1016/S0377-2217(01)00312-5

Nield, K., \& Kozak, M. (1999). Quality certification in the hospitality industry: analyzing the benefits of ISO 9000. The Cornell Hotel and Restaurant Administration Quarterly, 40, 40-5. http://dx.doi.org/10.1177/001088049904000215

Oliver, J., \& Qu, W. (1999). Cost of quality reporting: some Australian evidence. International Journal of Applied Quality Management, 2(2), 233-50. http://dx.doi.org/10.1016/S10964738(99)80092-X

Padma, P., Ganesh, L., \& Rajendran, C. (2008). A study on the ISO 14000 certification and organizational performance of Indian manufacturing firms. Benchmarking: An International Journal, 15, 73-100. http://dx.doi.org/10.1108/14635770810854353

Pan, J.N. (2003). A comparative study on motivation for and experience with ISO 9000 and ISO 14000 certification among Far Eastern countries. Industrial Management \& Data Systems, 103(8), 564-78. http://dx.doi.org/10.1108/02635570310497611

Parast, M.M., Adams, S.G., \& Jones, E.C. (2011). Improving Operational and Business Performance in the Petroleum Industry through Quality Management. International Journal of Quality \& Reliability Management, 28, in press. http://dx.doi.org/10.1108/02656711111121825

Petroni, A. (2001). Developing a methodology for analysis of benefits and shortcomings of ISO 14001 registration: lessons from experience of a large machinery manufacturer. Journal of Cleaner Production, 9, 351-64. http://dx.doi.org/10.1016/S0959-6526(00)00077-9

Pinar, M., \& Ozgur, C. (2007). The long-term impact of ISO 9000 certification on business performance: a longitudinal study using Turkish stock market returns. The Quality Management Journal, 14(4), 21-40.

Poksinska, B., Dahlgaard, J., \& Eklund, J. (2003). Implementing ISO 14000 in Sweden: motives, benefits and comparisons with ISO 9000. International Journal of Quality \& Reliability Management, 20, 585-606. http://dx.doi.org/10.1108/02656710310476543

Posinska, B., Dahlgaard, J.J., \& Antoni, M. (2002). The sate of ISO 9000 certification: a study of Swedish organizations. The TQM Magazine, 14(5), 297-306. http://dx.doi.org/10.1108/09544780210439734

Potoski, M., \& Prakash, A. (2005). Covenants with weak swords: ISO 14001 and facilities' environmental performance. Journal of Policy Analysis and Management, 24, 745-69. http://dx.doi.org/10.1002/pam.20136

Powell, T.C. (1995). Total quality management as competitive advantage: a review and empirical study. Strategic Management Journal, 16, 15-37. http://dx.doi.org/10.1002/smj.4250160105 
Prajogo, D.I., \& Sohal, A.S. (2006). The relationship between organization strategy, total quality management (TQM), and organization performance-the mediating role of TQM. European Journal of Operational Research, 168, 35-50. http://dx.doi.org/10.1016/j.ejor.2004.03.033

Psomas, E.L., \& Fotopoulos, C.V. (2009). A meta analysis of ISO 9001:2000 research findings and future research proposals. International Journal of Quality and Service Sciences, 1(2), 128-144. http://dx.doi.org/10.1108/17566690910971418

Quazi, H. (1999). Implementation of an environmental management system: the experience of companies operating in Singapore. Industrial Management \& Data Systems, 99, 302-11. http://dx.doi.org/10.1108/02635579910262526

Quazi, H. (2001). Sustainable development: integrating environmental issues into strategic planning. Industrial Management \& Data Systems, 101, 64-70. http://dx.doi.org/10.1108/02635570110384339

Quazi, H.A., \& Jacobs, R.L. (2004). Impact of ISO 9000 certification on training and development activities. An exploratory study. International Journal of Quality \& Reliability Management, 21(5), 497-517. http://dx.doi.org/10.1108/02656710410536545

Ragothaman, S., \& Korte, L. (1999). The ISO 9000 international quality registration: an empirical analysis of implications for business firms. International Journal of Applied Quality Management, 2(1), 59-73. http://dx.doi.org/10.1016/S1096-4738(99)80004-9

Renuka, S.D., \& Venkateshwara, B.A. (2006). A comparative study of human resource management practices and advanced technology adoption of SMEs with and without ISO certification. Singapore Management Review, 28, 41-61.

Rodríguez-Escobar, J.A., González-Benito, J., \& Martínez-Lorente, A.R. (2006). An analysis of the degree of small companies' dissatisfaction with ISO 9000 certification. Total Quality $\begin{array}{llll}\text { Management } \& \text { Business } & \text { 5xcellence, }\end{array}$ http://dx.doi.org/10.1080/14783360500528304

Rondinelli, D.A., \& Vastag, G. (2000). Panacea common sense or just a label? The value of ISO 14001 environmental management systems. European Management Journal, 18, 499-510. http://dx.doi.org/10.1016/S0263-2373(00)00039-6

Russo, M. (2009). Explaining the impact of ISO 14001 on emission performance: a dynamic capabilities perspective on process and learning. Business Strategy and the Environment, 18, 307-19. http://dx.doi.org/10.1002/bse.587

Ruzevicius, J., Adomaitiene, R., \& Sirvidaite, J. (2004). Motivation and efficiency of quality management systems implementation: a study of Lithuanian organizations. Total Quality $\begin{array}{llll}\text { Management } \quad \text { \& } \quad \text { Business } \quad \text { Excellence, } & 15(2), 89 .\end{array}$ http://dx.doi.org/10.1080/1478336032000149018

Sampaio, P., Saraiva, P., \& Rodrigues, A.G. (2009). ISO 9001 certification research: questions, answers and approaches. International Journal of Quality \& Reliability Management, 26(1), 38-58. http://dx.doi.org/10.1108/02656710910924161 
Samson, D., \& Terziovski, M. (1999). The relationship between total quality management practices and operational performance. Journal of Operations Management, 17, 393-409. http://dx.doi.org/10.1016/S0272-6963(98)00046-1

Santos, L., \& Escanciano, C. (2002). Benefits of the ISO 9000:1994 version. Some considerations to reinforce competitive advantage. International Journal of Quality \& Reliability Management, 19(3), 321-44. http://dx.doi.org/10.1108/02656710210415703

Schylander, E., \& Martinuzzi, A. (2007). ISO 14001 - Experiences, effects and future challenges: a national study in Austria. Business Strategy and the Environment, 16, 133-47. http://dx.doi.org/10.1002/bse.473

Shahin, A., \& Dabestani, R. (2011). A feasibility study of the implementation of total quality management based on soft factor. Journal of Industrial Engineering and Management, 4(2), 258-280. http://dx.doi.org/10.3926/jiem.2011.v4n2.p258-280

Sharma, D.S. (2005). The association between ISO 9000 certification and financial performance. The International Journal of Accounting, 40, 151-72. http://dx.doi.org/10.1016/j.intacc.2005.01.011

Simmons, B.L., \& White, M.A. (1999). The relationship between ISO 9000 and business performance: does registration really matter? Journal of Managerial Issues, 11(3), 330-43.

Singels, J., Ruël, G., \& van de Water, H. (2001). ISO 9000 series certification and performance. International Journal of Quality \& Reliability Management, 18(1), 62-75. http://dx.doi.org/10.1108/02656710110364477

Singh, P.J. (2008). Empirical assessment of ISO 9000 related management practices and performance relationships. International Journal of Production Economics, 113, 40-59. http://dx.doi.org/10.1016/j.ijpe.2007.02.047

Singh, P.J., Feng, M., \& Smith, A. (2006). ISO 9000 series of standards: comparison of manufacturing and service organisations. International Journal of Quality \& Reliability Management, 13(2), 122-42. http://dx.doi.org/10.1108/02656710610640916

Sun, H. (2000). Total quality management, ISO 9000 certification and performance improvement. International Journal of Quality \& Reliability Management, 17(2), 168-79. http://dx.doi.org/10.1108/02656710010304573

Szymanski, M., \& Tiwari, P. (2004). ISO 14001 and the reduction of toxic emissions. Policy Reform, 7, 31-42. http://dx.doi.org/10.1080/1384128042000219717

Tan, L. (2005). Implementing ISO 14001: is it beneficial for firms in newly industrialized Malaysia? Journal of Cleaner Production, 13, 397-404. http://dx.doi.org/10.1016/j.jclepro.2003.12.002

Tan, L-P., \& Sia, L-T. (2001). ISO 9000: the answer for total quality management implementation? The Malaysian case. Total Quality Management, 12(2), 223-29. http://dx.doi.org/10.1080/09544120120011442 
Tang, S.L., \& Kam, C.W. (1999). A survey of ISO 9001 implementation in engineering consultancies in Hong Kong. International Journal of Quality \& Reliability Management, 16(6), 562-74. http://dx.doi.org/10.1108/02656719910249810

Terziovski, M., \& Power, D. (2007). Increasing ISO 9000 certification benefits: a continuous improvement approach. International Journal of Quality \& Reliability Management, 24(2), 141-63. http://dx.doi.org/10.1108/02656710710722266

Terziovski, M., Power, D., \& Sohal, A. (2003). The longitudinal effects of the ISO 9000 certification process on business performance. European Journal of Operational Research, 146, 580-95. http://dx.doi.org/10.1016/S0377-2217(02)00252-7

Terziovski, M., Samson, D., \& Dow, D. (1997). The business value of quality management systems certification. Evidence from Australia and New Zealand. Journal of Operations Management, 15, 1-18. http://dx.doi.org/10.1016/S0272-6963(96)00103-9

Tsekouras, K., Dimara, E., \& Skuras, D. (2002). Adoption of a quality assurance scheme and its effect on firm performance: a study of Greek firms implementing ISO 9000. Total Quality Management, 13, 827-41. http://dx.doi.org/10.1080/0954412022000010163

van der Wiele, A., Williams, A.R.T., Brown, A., \& Dale, B.G. (2001). The ISO 9000 series as a tool for organisational change. Business Process Management Journal, 7(4), 323-31. http://dx.doi.org/10.1108/EUM0000000005731

Vloeberghs, D., \& Bellens, J. (1996). ISO 9000 in Belgium: experience of Belgian quality managers and HRM. European Management Journal, 14(2), 207-11. http://dx.doi.org/10.1016/0263-2373(95)00065-8

Wahba, H. (2008). Does the market value corporate environmental responsibility? An empirical examination. Corporate Social Responsibility and Environmental Management, 15, 89-99. http://dx.doi.org/10.1002/csr.153

Wayhan, V.B., Kirche, E.T., \& Khumawala, B.M. (2002). ISO 9000 certification: the financial performance implications. Total Quality Management, 13, 217-31. http://dx.doi.org/10.1080/09544120120102450

Wee, Y., \& Quazi, H. (2005). Development and validation of critical factors of environmental management. Industrial Management \& Data Systems, 105, 96-114. http://dx.doi.org/10.1108/02635570510575216

Wilkinson, G., \& Dale, B. (1999a). Integrated management systems: an examination of the concept and theory. The TQM Magazine, 11, 95-104. http://dx.doi.org/10.1108/09544789910257280

Wilkinson, G., \& Dale, B. (1999b). Models of management system standards: a review of the integration issues. International Journal of Management Reviews, 1, 279-98. http://dx.doi.org/10.1111/1468-2370.00016

Williams, J.A. (2004). The impact of motivating factors on implementation of ISO 9001:2000 registration process. Management Research News, 27(1-2), 74-84. http://dx.doi.org/10.1108/01409170410784365 
Yin, H., \& Schmeidler, P. (2009). Why do standardized ISO 14001 environmental management systems lead to heterogeneous environmental outcomes. Business Strategy and the Environment, 18, 469-86. http://dx.doi.org/10.1002/bse.629

Yiridoe, E., Clark, J., Marett, G., Gordon, R., \& Duinker, P. (2003). ISO 14001 EMS standard registration decisions among Canadian organizations. Agribusiness, 19, 439-57. http://dx.doi.org/10.1002/agr.10069

Zaramdini, W. (2007). An empirical study of the motives and benefits of ISO 9000 certification: the UAE experience. International Journal of Quality \& Reliability Management, 24(5), 472-91. http://dx.doi.org/10.1108/02656710710748358

Zeng, S., Tam, C., Tam, V., \& Deng, Z. (2005). Towards implementation of ISO 14001 environmental management systems in selected industries in China. Journal of Cleaner Production, 13, 645-56. http://dx.doi.org/10.1016/j.jclepro.2003.12.009

Zeng, S., Tian, P., \& Shi, J. (2005). Implementing integration of ISO 9001 and ISO 14001. Managerial Auditing Journal, 20, 394-407. http://dx.doi.org/10.1108/02686900510592070

Zeng, S.X., Tian, P., \& Tam, C.M. (2005). Quality assurance in design organisations: a case study in China. Managerial Auditing Journal, 20(7), 679-90. http://dx.doi.org/10.1108/02686900510611221

Zhao, X., Maheshwari, S., \& Zhang, J. (1995). Benchmarking quality practices in India, China and Mexico. Benchmarking for Quality Management \& Technology, 2(3), 20-40.

Zutshi, A., \& Sohal, A. (2004). Environmental management system adoption by Australasian organisations: part 1: reasons, benefits and impediments. Technovation, 24, 335-57. http://dx.doi.org/10.1016/S0166-4972(02)00053-6

Zutshi, A., \& Sohal, A. (2005). Integrated management system: the experiences of three Australian organisations. Journal of Manufacturing Technology Management, 16, 211-32. http://dx.doi.org/10.1108/17410380510576840

Journal of Industrial Engineering and Management, 2012 (www.jiem.org)

El artículo está con Reconocimiento-NoComercial 3.0 de Creative Commons. Puede copiarlo, distribuirlo y comunicarlo públicamente siempre que cite a su autor y a Intangible Capital. No lo utilice para fines comerciales. La licencia completa se puede consultar en http://creativecommons.org/licenses/by-nc/3.0/es/ 